\title{
KNOWLEDGE OF THE DEFINITION OF EUTHANASIA: STUDY WITH DOCTORS AND CAREGIVERS OF ALZHEIMER'S DISEASE PATIENTS
}

\author{
Luciana Pricoli Vilela ${ }^{1}$, Paulo Caramelli*2 \\ Trabalho realizado na Faculdade de Medicina da UFMG, Belo Horizonte, MG, e Faculdade de Medicina da USP, S. Paulo, SP
}

*Correspondência:

Prof. Dr. Paulo Caramelli Departamento de Clínica

Médica

Faculdade de Medicina da

Universidade Federal de

Minas Gerais

Av. Prof. Alfredo Balena,

190 - Sala 246

30130-100,

Belo Horizonte (MG) - Brasil

Tel: (31) 3409-9746

Fax: (31) 3409-9745

caramelp@usp.br

\section{SUMMARY}

BACKGROUND. Euthanasia is an increasingly debated subject among specialized professionals and also among lay people, even in countries such as Brazil where it is not authorized. It is questionable, however, if the concept of euthanasia is well known by these persons.

Овлестіve. The goal of this study was to investigate knowledge about the definition of euthanasia by family caregivers of patients with dementia and by specialized physicians and also to investigate their personal opinion on this topic.

Methods. We prospectively interviewed 30 physicians from three different medical specialties and 40 family caregivers of patients with Alzheimer's disease using a structured questionnaire. Two clinical vignettes were also presented to the physicians in order to ascertain their personal opinion about euthanasia.

REsults. Among the caregivers, 10 (25.0\%) knew the correct definition of euthanasia. Regarding their personal view, nine (22.5\%) were in favor, while 20 (50.0\%) were against. The remaining 11 (27.5\%) caregivers were unable to define their position. Among the physicians, 19 (63.3\%) gave a coherent answer regarding the definition of euthanasia. When they were presented with the clinical vignettes, less than $50 \%$ of them were in favor of euthanasia.

Conclusion. The definition of euthanasia was unknown by most of the lay individuals and also by one third of the physicians. Although it is not officially approved in Brazil, a small proportion of family caregivers and also of specialized physicians would be in favor of the practice of euthanasia.

KEY woRDS: Euthanasia. Dementia. Alzheimer's disease. End of life.

\section{INTRODUCTION}

Euthanasia is a polemic topic not only in the medical area but also in the social, political, philosophical and religious domains. Presented with cases such as that of Terry Schiavo ${ }^{1,2,3}$, both the lay and specialized public keep abreast with this complex issue of end of life care. Much is said about euthanasia but apparently definitions of the word are oversimplified, as is often the case, when technical terms are used in non-specialized environments or in a more universal way.

After all, what is euthanasia? Is there a consensus about the definition? Is the term correctly used by the lay public and also by physicians? Are these people always referring to the same thing?

These questions are far from trivial. Due to aging of the world population, also in developing countries such as Brazil ${ }^{4}$, there is a growing prevalence of degenerative diseases which in turn can lead to a state of health called "end-stage". In end-stage scenarios the discussion on euthanasia and related issues becomes central.
Among the conditions that may lead to an end-stage state, dementia ranks high, especially in the elderly with a worldwide prevalence ranging from $2.2 \%$ to $9.4 \%$ among individuals aged 65 years and over. Of all causes of dementia, Alzheimer's disease (AD) is the most common according to the majority of world studies ${ }^{5}$ and also to a Brazilian population study ${ }^{6}$.

Since $A D$ is a progressive neurodegenerative disorder, with an average survival rate of eight years after being diagnosed, patients often evolve to a critical cognitive and vegetative condition ${ }^{7}$. Family caregivers and health professionals who are in regular contact with such patients may start to question issues concerning end of life care, including euthanasia. In this sense, a few years ago, authorities in the Netherlands approved euthanasia for a patient suffering from $A D$ who at the beginning of his illness stated that he did not want to endure the full course of the disease and asked for an assisted suicide. ${ }^{8}$

The term euthanasia comes from the Greek (eu-thanatos) and literally means "good death". It was adopted by Medicine to mean accelerating patient death to avoid undue suffering from a disease. Since it is a broad concept, many variations are in 
use describing different "kinds of euthanasia", the most common of which are "active euthanasia", "passive euthanasia" and "disthanasia"9, 10, the latter being the most recently proposed.

Active euthanasia refers to an act, such as a lethal injection to achieve immediate, or almost immediate, death of the patient; whereas passive euthanasia refers to hasten death by omission of medical interventions. Hence, "euthanasia" followed by any other term, intends death and so implies - or at least should imply - the same ethical aspects, regardless of how death is achieved. ${ }^{11}$

On the other hand, if the intention is to avoid an obstinate therapeutic approach, i.e. disthanasia (dis-thanatos, "death with difficulty") or futile treatment which prolongs the process of dying, the term "passive euthanasia" is no longer applicable. Therefore, in clinical practice it is very difficult to decide up to what point to invest in an end-stage patient therapy, without constituting one form of euthanasia or another. An interesting proposition may be that, when faced with the possibility of foregoing or suspending treatment, the health professionals ask themselves if they will have achieved their objective should the patient does not die. If the answer is "no", the intention would be passive euthanasia; if it is "yes", the purpose of simplifying treatment would be achieved without any additional suffering from the "therapeutic" act ${ }^{12}$. In this last situation, an obstinate therapeutic action would have been avoided.

The aim of this work was to investigate knowledge about euthanasia definitions and opinions of AD patient caregivers and physicians of three different medical specialties, on this practice. Literature on euthanasia is very extensive. However, for this project, whereby people were asked about conceptual aspects, the available data is very scarce. Currently, there are only a few studies published on euthanasia definitions among health professionals ${ }^{13,14}$, and no studies among the lay public are available.

\section{Methods}

\section{Caregivers}

Forty family caregivers of patients with probable $A D$, according to NINCDS-ADRDA diagnostic criteria ${ }^{15}$, were interviewed. All patients were at moderate or severe stages of dementia, according to DSM III-R criteria ${ }^{16}$, and were followed by clinicians at the Cognitive and Behavioral Neurology Outpatient Clinic from the Hospital das Clínicas of the University of São Paulo School of Medicine (HC-FMUSP), a publicuniversity affiliated hospital in São Paulo, Brazil, or at a private clinic, also in the city of São Paulo.

The caregivers were chosen randomly according to their presence in the outpatient clinic on days when the research team was available to conduct interviews. Twenty family caregivers from the public service (HC-FMUSP) and twenty from the private clinic were invited to participate, none of whom refused.

The participants signed a written consent form previously approved by the Ethics in Research Committee from the $\mathrm{HC}$ FMUSP, and answered the questions in a single interview session, without any previous information. The questionnaire was administered as a semi-structured interview, lasting twenty minutes on the average, although no time limit was imposed for answers. The questionnaire was devised specifically for this research and consisted of 30 questions on the following topics: main socio-demographic characteristics, socioeconomic level (divided into six levels according to a specific scale) ${ }^{17}$, impact on the caregivers' life regarding material and emotional points of view (some questions were based on the Zarit Burden Interview ${ }^{18}$, a questionnaire on caregiver burden), knowledge about the disease (diagnosis, treatment and prognosis) corresponding to some issues that were not relevant to this paper, and finally, knowledge about euthanasia definitions and their opinions about it.

For the purpose of statistical analysis, data from caregivers of patients from HC-FMUSP and that of patients from the private clinic were initially considered in separate. The statistical program MedCalc version 7.2.1.0 for Windows was used. The Kolmogorov-Smirnov test defined normal distribution for age in both samples, enabling use of the Student's t test to compare both groups. The chi-square test was employed to compare other variables from both groups.

\section{Physicians}

Besides the caregivers, 30 specialized physicians were also interviewed: ten working in the emergency room, ten from Intensive Care Units (ICU) and ten clinicians (five geriatricians and five neurologists). All physicians participating were randomly selected and were medical staff members of the $\mathrm{HC}$ FMUSP, where interviews were conducted. All invited physicians accepted to participate in the project.

The participants signed a written consent form previously approved by the Ethics in Research Committee from the HCFMUSP and answered the questions in a single interview session, without any previous information. The questionnaire was administered as a semi-structured interview, lasting fifteen minutes on the average, although no time limit was imposed for the answers. The questionnaire was devised specifically for this study and consisted of about 20 items divided into a number of clinical vignettes based on previous studies ${ }^{19,20}$ and on the following topics: number of years since graduation, self-evaluation concerning palliative treatment, frequency of dealing with $\mathrm{AD}$ patients and knowledge about euthanasia.

\section{Questions about euthanasia}

The following questions about the concept of euthanasia were asked to physicians and caregivers alike:

What do you understand by euthanasia?

a) It is to let one die without any kind of medical assistance

b) It is to let one die without sophisticated medical assistance (mechanical ventilation, dialysis, feeding directly in the vein...)

c) It is to induce death by, for instance, giving a medication with lethal effect

d) It is the attempt to reduce the patient's suffering by giving medications that control pain but shorten life

e) It is to give the patient a lethal medication allowing them to take the decision to shorten life themselves

f) I do not know 


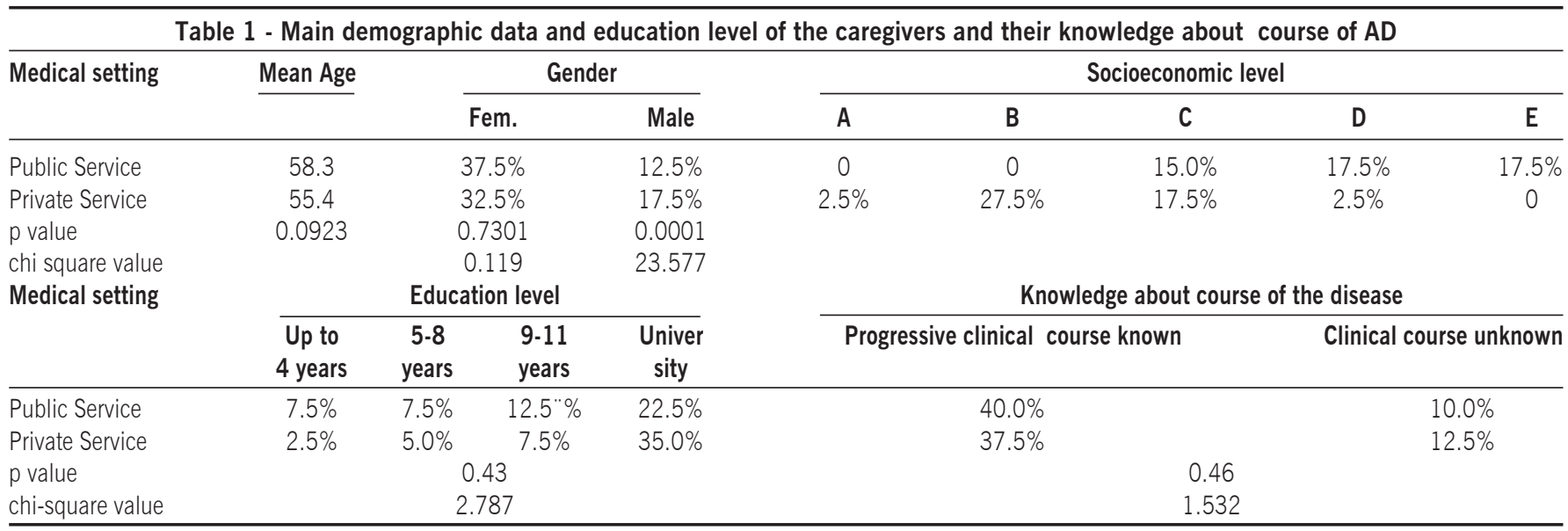

\begin{tabular}{|c|c|c|c|c|c|c|c|}
\hline \multicolumn{8}{|c|}{ Table 2 - Definition of euthanasia } \\
\hline Caregivers & $\frac{a}{5.0 \%(2)}$ & $\frac{b}{15.0 \%(6)}$ & $\frac{\mathbf{c}}{25.0 \%(10)}$ & $\frac{d}{20.0 \%(8)}$ & $\frac{e}{15.0 \%(6)}$ & $\frac{\text { f/other* }}{20.0 \%(8)}$ & $\frac{\text { Total }}{100 \%(40)}$ \\
\hline $\begin{array}{l}\text { Physicians } \\
\text { What do yo } \\
\text { a) It is to le } \\
\text { b) It is to le } \\
\text { c) It is to in } \\
\text { d) It is the } \\
\text { e) It is to gi } \\
\text { f) I do not }\end{array}$ & $\begin{array}{l}3.3 \%(1) \\
\text { tand by eut } \\
\text { without an } \\
\text { without so } \\
\text { ath by givin } \\
\text { o reduce pa } \\
\text { atient a leth }\end{array}$ & $\begin{array}{l}23.3 \%(7) \\
\text { medical ass } \\
\text { d medical as } \\
\text { ance, a med } \\
\text { ering by givi } \\
\text { ation to let h }\end{array}$ & $\begin{array}{l}\text { mechanical v } \\
\text { ith lethal effec } \\
\text { ations that cor } \\
\text { ke by himself/ }\end{array}$ & $\begin{array}{l}6.6 \%(2) \\
\text {, dialysis, fee } \\
\text { but shorten } \\
\text { he decision t }\end{array}$ & $\begin{array}{l}3.3 \%(1) \\
\text { ctly in the ve } \\
\text { his/her life }\end{array}$ & & \\
\hline
\end{tabular}

Considering that euthanasia is an act (which can include omission or suspension of specific treatments) intended to accelerate the death process of patients to relieve them from their suffering (see Introduction), the most fitting option would be "c", which clearly states or perhaps overstates, using the words "induce someone's death" by "lethal" treatment. However, option "b" could be interpreted as a kind of euthanasia (i.e. passive euthanasia) or as a way to avoid disthanasia, given that the intention behind omission of "sophisticated medical assistance" has not been made explicit. Hence, to have a coherent answer, the respondent must consider passive euthanasia, which is specifically addressed later in the questionnaire.

Option "a" represents omission of help and thus, by definition cannot be mistaken for passive euthanasia. Option "e" corresponds to assisted-suicide ${ }^{21}$. Finally, option "d" relates to so-called "double-effect" therapy²2

\section{RESULtS}

\section{Caregivers}

The subgroup of caregivers interviewed in the private clinic did not differ statistically from the group assessed at the public hospital in relation to age $(p=0.09)$, gender $(p=0.73)$, education level $(p=0.43)$, number of years dedicated to patients' care $(p=0.52)$ and knowledge about the clinical course of the disease $(p=0.46)$. The only difference observed between both groups was in relation to socioeconomic level, with the private clinic subgroup being wealthier $(p=0.0001)$.

Considering the whole caregiver group, mean age was 60.7 years, $70.0 \%(n=28)$ were women and $30.0 \%(n=12)$ were men. In relation to educational level, $10.0 \%(n=4)$ had 0 to 4 years; $12.5 \%(n=5)$ with 5 to 8 years; $20.0 \%(n=8)$ 9 to 11 years, and $57.5 \%(n=23)$ had more than 11 years of formal education (Table1).

Regarding the definition of euthanasia, no significant differences between the two subgroups of caregivers were found $(p=0.24)$. Table 2 presents the answers from the 40 caregivers on this topic.

Euthanasia was accepted by $22.5 \%(n=9)$ of the overall group of caregivers, while $50.0 \%(n=20)$ were against it and $27.5 \%(n=11)$ had no opinion. No significant differences were observed between these three groups of caregivers in relation to the scores on the Zarit Burden Interview. Among the subjects who knew the precise definition of euthanasia (option "c"), only one $(2.5 \%$ of the sample of 40 caregivers or $10.0 \%$ of the 10 caregivers who chose option "c") was in favor of euthanasia. In other words, only one out of the nine individuals that were proeuthanasia clearly knew its correct definition. Since option "b" was ambiguous and two people who were in favor of euthanasia chose this option (5.0\% of the whole sample), it can be concluded that only three out of the ten individuals in favor of 
euthanasia knew its definition. It is important to mention that no definitions were given at any time.

\section{Physicians}

The mean age of the physicians interviewed was 38.5 years and the mean number of years since graduation was 14.5 years. As mentioned previously, the professionals interviewed were drawn from different medical specialties: 10 clinicians (five neurologists and five geriatricians), 10 ICU and 10 emergency room physicians.

In relation to the question about the definition of euthanasia, $40.0 \%(n=12)$ answered option "c". Other results can be seen in Table 2 . It is noteworthy that $9.9 \%$ $(n=3)$ chose more than one option (only one of them choosing options "b" and "c", which is understandable). When asked if they thought that "active euthanasia" and "passive euthanasia" were equivalent or different, only $6.7 \%$ $(n=2)$ stated they were equivalent while 93.3\% $(n=28)$ considered them different. After answering the question about definition of euthanasia, physicians were asked to state which kind of euthanasia they were referring to. From the 12 physicians ( $40.0 \%$ of the total) who answered option "c", 10 were referring to active euthanasia, while from the $23.3 \%$ $(n=7)$ who answered option "b", all were referring to passive euthanasia. Hence, we consider that $56.6 \% \%(n=17)$ of the physicians gave a coherent answer regarding the definition of euthanasia.

The following question was put to assess the opinion of the physicians about euthanasia:

Concerning suspension of minimal support (that is, intravenous fluids and parenteral nutrition) versus administration of medications which provoke death:

a) The first is more acceptable than the second because it is "let die", whereas the other is "to kill"

b) Both approaches lead to death but the second is preferable as it reduces suffering

c) Both are unacceptable

According to the definitions of euthanasia, suspension of minimal support means passive euthanasia, since death is imminent if there are not "minimal" conditions to keep the patient alive (hydration and nutrition). The administration of medications which provoke death is active euthanasia. The question does not mention whether drugs represent palliative medicines that shorten life as a secondary effect and so to think about double-effect therapy. Therefore, both options can be considered euthanasia. Thirteen physicians (43.3\%) selected option "a", seven (23.3\%) selected "b", nine (30.0\%) selected "c" and one (3.3\%) selected more than one option.

Besides this question, physicians' approaches in concrete situations were also evaluated, using clinical vignettes. The first vignette described a 72 year-old patient who had advanced dementia and suffered a car accident, going into coma and was intubated, without any prospect of recovery. When asked about their personal attitudes, 14 physicians (46.6\%) were in favor of suspending mechanical ventilation and 13 (43.3\%) would do so if the family requested it. Suspension of mechanical ventilation without weaning conditions, intending patient's death, may be a kind of euthanasia.
The second case (fourth of the questionnaire) reported a 40 year-old man who, after acute myocardial infarction had a cardiac arrest and went into coma, breathing spontaneously but without prospect of neurological recovery. Three family contexts were proposed for the patient with the following options of procedure for each situation:

a) You maintain total support, including mechanical ventilation if needed

b) You forego additional therapies (including mechanical ventilation or antibiotics if needed), but maintain present care

c) You do not continue treatment (including intravenous fluids and nutrition), and let the patient die slowly (with minimal discomfort using medications, if needed)

d) You administrate sedation/morphine to let the patient die quickly

In cases where the patient has no family, two physicians $(6.6 \%)$ would carry out active euthanasia (option "d"). These same physicians would intervene according to family wishes, if the patient had family: they would give total support if requested or they would forego additional treatment if they were requested to do so.

When analyzing the answers from other physicians, in cases of patients with no family, it is evident that personal opinions and decisions are prevalent. In this context, thirteen physicians (43.3\%) would give total support to the patient (option "a") and would do the same in cases where the family requested this; only five physicians (16.6\%) would forego additional therapies (option "b") if this were the family's wish. Fourteen physicians (46.6\%) would select option "b" if the patient had no family and the physicians had to decide. Thirteen physicians (43.3\%) would maintain this position if the family directly requested not to use additional treatment and only six physicians $(20.0 \%)$ would change their position, giving total support when the family requested. Finally, if the patient had no family, one physician (3.3\%) would perform passive euthanasia (the intention is that the patient dies option "c"). Thus, in the case of the patient described above, only three physicians (10.0\%) would perform active or passive euthanasia (options "c" or "d").

\section{Discussion}

End of life health care assistance for patients with dementia and its related ethical aspects are topics of increasing relevance both in medical and social milieus. This work aimed to assess the knowledge about euthanasia in two different groups of individuals, lay people and physicians, both having direct contact with patients suffering from degenerative dementia that ultimately will reach the so called "end-stage" condition.

The study revealed that only $25 \%$ of caregivers knew the precise definition of euthanasia. If the concept included an additional option (i.e., passive euthanasia or to avoid disthanasia), $40 \%$ responded correctly. Of these caregivers, $22.5 \%$ were in favor of euthanasia, although only $7.5 \%$ of those who gave a coherent answer were in favor of it. Among the physicians, $63.3 \%$ gave a correct answer concerning the definition of euthanasia. In practice, $66.6 \%$ of them were in favor of one of the types of euthanasia (Table 3 ). 
Table 3 - Definition and position concerning euthanasia

\begin{tabular}{lcc}
\hline & $\begin{array}{c}\text { Knew the definition } \\
\text { of euthanasia }\end{array}$ & In favor of euthanasia \\
\hline Caregivers & $25.0 \%$ & $22.5 \%$ \\
Physicians & $63.3 \%$ & $66.6 \%$ \\
\hline
\end{tabular}

It can be concluded that the knowledge about euthanasia by the lay public is limited, even among people with good educational background. However, among physicians this lack of knowledge is not so marked, but may also be considered limited, given that they are qualified professionals working in an academic environment (university hospital).

In relation to the opinion about euthanasia, more than half of caregivers interviewed were against it. In case of the physicians, almost half of them considered euthanasia as an acceptable option of practice, that is, they would choose this in specific clinical situations, as outlined by their responses to the clinical vignettes. Results obtained for the two clinical situations are very different in relation to euthanasia. This difference is probably due to the fact that in the first case the patient was old and with previous dementia, and in the second, the patient had been a healthy adult.

Only 30\% of the physicians interviewed rejected euthanasia, while the remaining accepted at least one variation of this practice. However, a doubt still remains: if the term "euthanasia" had been used, would support for it have been the same? Indeed, it would have been interesting if the questionnaire had made this question explicitly to the caregivers, so that results could be compared.

Similar studies in other populations could not be found for comparison with the present results. In Brazil, the practice of euthanasia is not legally permitted. Nevertheless, it is clear that better understanding about the definitions and implications of euthanasia are necessary. Ignorance is always an enemy to be confronted, especially when referring to essential aspects such as life and death.

\section{ACKNOWLEDGEMENTS}

We are grateful to the Conselho Regional de Medicina do Estado de São Paulo (São Paulo State Medical Council), for providing Luciana Pricoli-Vilela with a scholarship (program of scientific research support in the research area of Medical Ethics, in 2000).

\section{Interest conflict: none}

\section{Resumo}

O CONHECIMENTO DA DEFINIÇÃo DE EUTANÁSIA: ESTUDO COM MÉDICOS E Cuidadores de pacientes Com doença de Alzheimer

Introdução. A eutanásia é um tema de crescente debate entre profissionais da área de saúde e também entre o púbico leigo, mesmo em países nos quais não é legalizada, como no Brasil. Entretanto, é questionável se a definição do termo é bem conhecida por essas pessoas.

OBJETIVo. O propósito do presente estudo foi investigar o conhecimento sobre a definição de eutanásia entre cuidadores familiares de pacientes com demência e médicos especialistas e suas opiniões a respeito do assunto.
MÉTODOS. Foram entrevistados prospectivamente 30 médicos de três especialidades diferentes e 40 cuidadores familiares de pacientes com doença de Alzheimer utilizando-se um questionário estruturado. Aos médicos também foram propostos dois casos clínicos com a intenção de conhecer suas opiniões sobre a eutanásia.

REsultados. Entre os cuidadores, 10 (25\%) sabiam a definição correta da eutanásia. A respeito de suas opiniões, nove (22,5\%) foram a favor, enquanto 20 (50\%) foram contra. Os demais 11 (27,5\%) cuidadores não foram capazes de definir suas posições. Entre os médicos, 19 (63,3\%) deram uma resposta coerente sobre a definição de eutanásia. Quando apresentados aos casos clínicos, menos de 50\% deles demonstraram, na prática, ser favoráveis.

Conclusão. A definição da eutanásia era pouco conhecida pela maioria dos indivíduos leigos e pela terça parte dos médicos entrevistados. Ainda que não seja oficialmente legalizada no Brasil, uma pequena proporção dos familiares cuidadores e dos médicos seria a favor de sua prática. [Rev Assoc Med Bras 2009; 55(3): 263-7]

Unitermos: Eutanásia. Demência. Doença de Alzheimer. Fim de vida.

\section{References}

1. Gostin LO. Ethics, the constitution, and the dying process: the case of Theresa Marie Schiavo. JAMA. 2005;293:2403-7

2. Charatan F. President Bush and Congress intervene in "right to die" case. BMJ. 2005;330:687.

3. Charatan F. President Bush and Congress intervene in "right to die" case. BMJ 2005;330:687.

4. Instituto Brasileiro de Geografia e Estatística (IBGE). Censo Demográfico 2000. Rio de Janeiro (RJ): Instituto Brasileiro de Geografia e Estatística; 2000.

5. Lopes MA, Bottino CMC. Prevalência de demência em diversas regiões do mundo: Análise dos estudos epidemiológicos de 1994 a 2000. Arq Neuropsiquiatr. 2002;60:61-9.

6. Herrera E Jr, Caramelli P, Silveira AS, Nitrini R. Epidemiologic survey of dementia in a community-dwelling Brazilian population. Alzheimer Dis Assoc Disord. 2002;16:103-8.

7. Gauthier S. Clinical diagnosis and management of Alzheimer's disease. $2^{\text {nd }}$ ed. London: Martin Dunitz; 2001.

8. Sheldon T. Dutch approve euthanasia for a patient with Alzheimer's disease. BMJ. 2005;330:1041.

9. Chao DVK, Chan NY, Chan WY. Euthanasia revisited. Fam Pract. 2002;19:128-34

10. Pessini L. Distanásia: até quando investir sem agredir? Bioética. 1996;4:1.

11. Rachels J. Active and passive euthanasia. N Engl J Med. 1975;292:78-80.

12. Garrard E, Wilkinson S. Passive euthanasia. J Med Ethics. 2005;31:64 - 68.

13. Ramirez-Rivera J, Ramos O. Euthanasia and relief of suffering: attitudes of medical students. Bol Asoc Med P R. 1995;87:164-6.

14. Van Holsteyn J, Trappenburg M. Citizens opinions on new forms of euthanasia. A report from the Netherlands. Patient Educ Couns. 1998:35:63-73.

15. McKhann G, Drachman D, Folstein M, et al. Clinical diagnosis of Alzheimer's disease: Report of the NINCDS-ADRDA Work Group under the auspices of Department of Heath and Human Services Task Force on Alzheimer's disease. Neurology. 1984;23:939-44.

16. American Psychiatry Association. DSM-III-R: Diagnostic and statistical manual of mental disorders.3rd ed. American Psychiatry Association, 1980

17. Graciano MIG, Lehfeld NAA, Neves-Filho A. Critérios de Avaliação socioeconômica: elementos de atualização - parte II. Serviço Social \& Realidade. 1996;5:171-201.

18. Zarit SH, Reever KE, Bach-Peterson J. Relatives of the impaired elderly: correlates of feelings of burden. Gerontologist. 1980;20:649-55.

19. Vincent J-L. Forgoing life-support in western European intensive care units: the results of an questionnaire. Crit Care Med. 1999;27:1626-33.

20. Sjökvist P, Nilstun T, Svantesson M, Berggren L. Withdrawal of life support who should decide? Int Care Med. 1999;25:949-54.

21. Lee MA, Nelson HD, Tilden VP, Ganzini L, Schmidt TA and Tolle SW. Legalizing assisted suicide - Views of physicians in Oregon. New Engl J Med. 1992;334:310-5.

22. American College of Physicians. ACP ethics manual, 3rd ed. Ann Intern Med. 1992;117: 947-60.

Artigo recebido: 13/04/08

Aceito para publicação: 24/07/08 